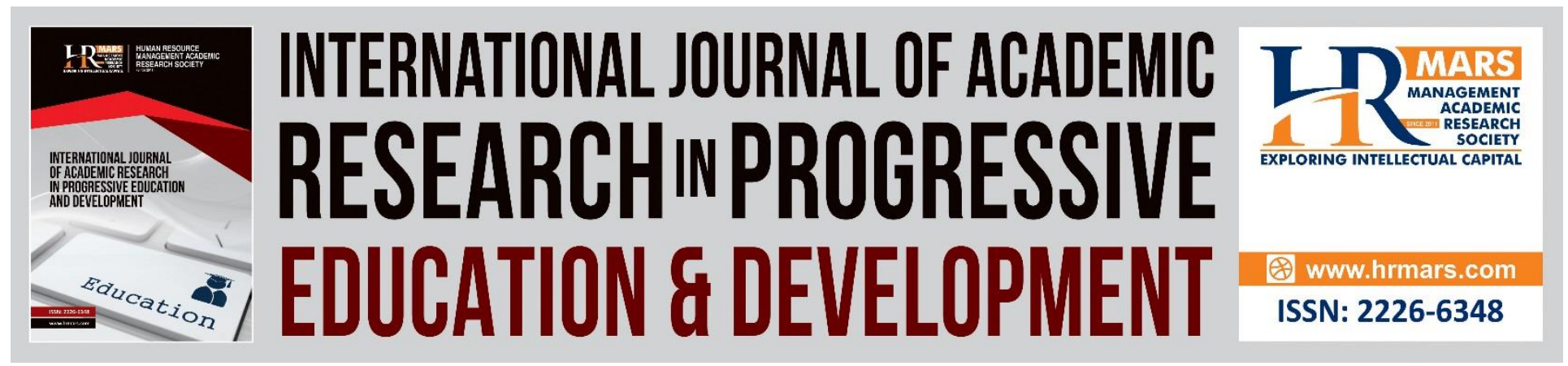

\title{
Extent of Provision and Utilization of Instructional Media for Biology Instruction in Secondary Schools in Ikwo Local Government Area of Ebonyi State
}

\author{
Ude, Veronica Chinonyelum \\ Ezugwu, Emmanuel Nwachukwu
}

To Link this Article: http://dx.doi.org/10.6007/IJARPED/v8-i1/5416 DOI: $10.6007 /$ IJARPED/v8-i1/5416

Received: 25 Dec 2018, Revised: 21 Jan 2019, Accepted: 10 Feb 2019

Published Online: 11 Feb 2019

In-Text Citation: (Ude \& Ezugwu, 2019)

To Cite this Article: Ude, V. C., \& Ezugwu, E. N. (2019). Extent of Provision and Utilization of Instructional Media for Biology Instruction in Secondary Schools in Ikwo Local Government Area of Ebonyi State. International Journal of Academic Research in Progressive Education and Development, 8(1), 22-31.

Copyright: (C) 2019 The Author(s)

Published by Human Resource Management Academic Research Society (www.hrmars.com)

This article is published under the Creative Commons Attribution (CC BY 4.0) license. Anyone may reproduce, distribute, translate and create derivative works of this article (for both commercial and non-commercial purposes), subject to full attribution to the original publication and authors. The full terms of this license may be seen at: http://creativecommons.org/licences/by/4.0/legalcode

Vol. 8, No. 1, 2019, Pg. 22 - 31

http://hrmars.com/index.php/pages/detail/IJARPED

JOURNAL HOMEPAGE

Full Terms \& Conditions of access and use can be found at

http://hrmars.com/index.php/pages/detail/publication-ethics 


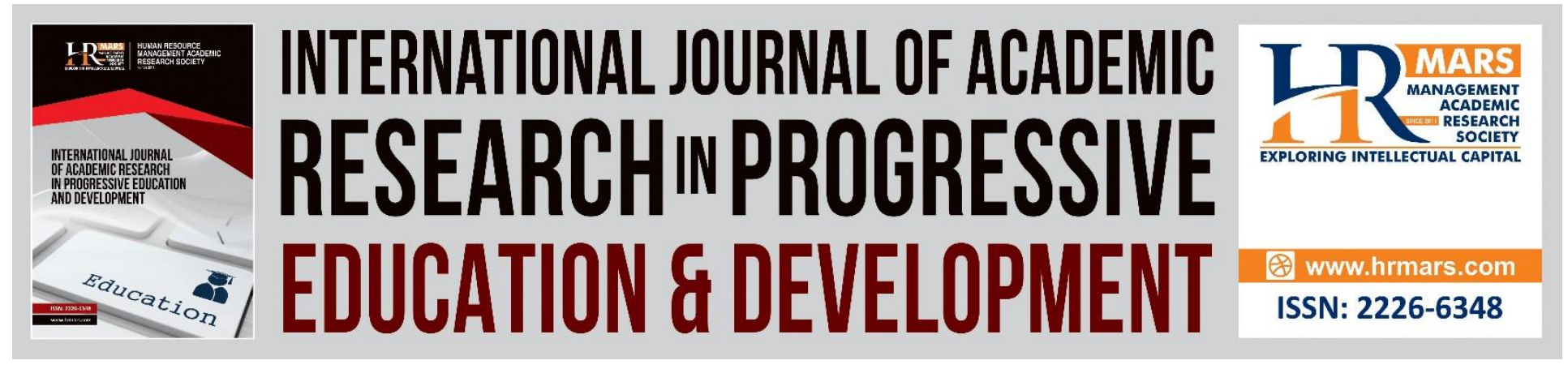

\title{
Extent of Provision and Utilization of Instructional Media for Biology Instruction in Secondary Schools in Ikwo Local Government Area of Ebonyi State
}

\author{
Ude, Veronica Chinonyelum Ph.D. \\ Department of Science and Vocational Education, Godfrey Okoye University, Enugu. \\ Email: drvcude@gmail.com \\ Ezugwu, Emmanuel Nwachukwu Ph.D. \\ Department of Science Basic Sciences, Institute of Management and Technology, Enugu. \\ Email: emmaezugw25@gmail.com
}

\begin{abstract}
This study investigated the extent of provision and utilization of instructional media to improve biology instruction in secondary schools. Four research questions and two hypotheses were formulated to guide the study. Descriptive survey research designed was adopted. The sample consisted of thirty two biology teachers of SS II and SS III drawn randomly from 127 teachers that made up the population. The instrument for data collection is structured questionnaire constructed by the researchers. The instrument was content and face validated by three experts, one from measurement and evaluation and two from science education. The reliability coefficient of the instrument was established using Crombach Alpha and found to be 0.74. The data for the study were analyzed using mean and standard deviation for research questions and t-test for hypotheses. The study revealed that non-projected media were provided and used to a large extent while projected media were provided and used to a very small extent. It was therefore recommended that instructional media both projected and non-projected should be made available to biology teachers by the school principals. Biology teachers should also make improvisations for instructions.
\end{abstract}

Keywords: Provision, Utilization, Instructional Media, Instruction, Secondary School.

\section{INTRODUCTION}

Biology is generally referred to as the study of life. It also deals with the inter-relationship organisms have with their environment. It is therefore necessary to teach biology in senior secondary schools in order to inculcate students' understanding of the structures and functions of living things. According to Ude, 2011, to produce experienced and qualified doctors, 
pharmacists, biology teachers and all those concerned with the study of animal and plant life, a good foundation in biology is required.

The nature of biology as a science subject makes it activity based and one that involves a creative process with a lot of techniques and a number of methods to make discoveries and developing of theories easy. As a result of this, it is important that teachers and students should be provided with instructional materials manipulate biology instruction for effective learning to take place. The implication is that biology should be taught as an activity oriented subject for students to acquire meaningful, functional and relevant knowledge.

Maduabum (2008) states that for biology to be taught effectively, teachers should organize it in an illustrative and investigative way using science equipment and allowing students make reports on the practical aspect and give considerable attention to supervision of their reports.

However, there is a lot of research work which have shown that students hardly study biology in an activity based fashion. For instance Chidume (2009) found that most biology teachers used lecture method and that few teachers applied demonstrations, laboratory, discussion, team teaching and field trip. Maduabum (2008) blamed delayed retention by the teachers on not using experimental method in teaching biology. It was also observed that the cause of students difficulty in learning the concepts of aspects of biology such as ecology, genetics, soil, morphology of higher plants, control and co-ordination are due to lack of consumable materials, insufficient time allocation for biology practicals, lack of science laboratory equipments, absence of conventional science laboratory in schools, inadequate qualification of biology teachers and lack of interest by the students.

For biology to be taught excitedly and students to reap its benefits, Igwe (2003) had also shown the types of laboratory materials and equipment that ought to be provided in our secondary schools. These include microscopes, glassware for storing specimens, computer, dust bins for refuse, thermometers and permanent equipment like insect cage, aquarium and water distiller. There should be adequate provision of consumable materials like cotton wool, chemicals (acids, bases, ethanol, Fehling's solution, methylated spirit) and litmus papers. It is common knowledge that principals of schools hardly provide these consumable materials until West African Examination Council (WAEC) examination is around the corner. This study is therefore out to investigate how the extent of provision and utilization of instructional materials has affected the handling of biology instruction in secondary schools in Ikwo Local Government Area of Ebonyi State.

It was also observed that students are not interested in studying science education in higher institutions except when they had realized that there was no other option left for them (Igwe, 2003). In this case they come in without positive attitude and positive academic self-concept. Most of them enter for biology for which they perform poorly eventually (WAEC Chief Examiners' report, 2015).

These problems tend to militate against the effective biology instruction in secondary schools coupled with possible lack of materials needed to stimulate instruction as well. Alumode (2002) looked into the supposed educational backwardness of EbonyiState and opined that there is high incidence of ill-qualifiedteachers.

This mostly affects the science of which biology is one because a biology teacher who is not qualified would not be capable of effectively manipulating materials for biology instruction. Igwe 
(2004) had observed the difficulty of integrating theory with practical in science and opined that this has adversely affected the teaching of biology in secondary schools. This could be attributed to high dearth of instructional materials that are supposed to elucidate the complex concepts in biology during instructions.

Eya (2011) observed that instructional materials show inaccessible process, materials events, things, changes in time, speed and space, which are helpful in understanding the scientific concept. They promote greater acquisition and higher retention of factual knowledge. They contribute to the development of attitude and behavioural change.

They challenge students' creativity and help to overcome physical disabilities and hindrances to learning in the subject matter.

Based on the above observation, there is need for investigation into the extent of provision and utilization of instructional media during biology instruction in secondary schools. The researcher feels therefore that if the problems confronting the teaching and learning of biology in secondary schools in Ikwo were not resolved especially through an empirical study, the great importance of biology to the knowledge of life and relevance to other professional courses like medicine, pharmacy and agriculture would be jeopardized.

\section{Statement of the Problem}

The importance of biology to humanity cannot be overemphasized. Real understanding of this subject can improve the health of the society and prolong life expectancy of individuals. A lot of problems are militating against the teaching and learning of biology in secondary schools especially in Ikwo Local Government Area of Ebonyi State. These problems range from lack of adequate qualified biology teachers, shortage of fund, inadequate consumable instructional materials, insufficient time allocation forpracticals and lack of equipment. The question is 'could the provision and utilization of instructional materials improve biology instruction in secondary schools in Ikwo L.G.A.? Therewill surely be improvement. The researchers therefore investigated the extent of provision and utilization of these instructional materials during biology instruction in Ikwo L.G.A.

\section{Purpose of the Study}

The main purpose of this study is to find out the extent of provision and utilization of instructional media to improve biology instruction in secondary schools in Ikwo L.G.A, Ebonyi State. Specifically the purpose of the study is to

1. Determine the extent of provision and utilization of consumable science materials to biology instruction in secondary schools in Ikwo L.G.A., Ebonyi State.

2. Ascertain the extent of the provision and utilization of science equipment to improve biology instruction in secondary schools in Iwo L.G.A.

3. Find out the extent of the provision and utilization of charts and models to improve the insufficient time allocation for biology practicals during biology instructional in secondary schools in Ikwo L.G.A.

4. Determine the extent of the provision and use of practical manuals to improve integration of theory and practicals in biology instructions in secondary schools in Ikwo L.G.A. 
INTERNATIONAL JOURNAL OF ACADEMIC RESEARCH IN PROGRESSIVE EDUCATION AND

DEVELOPMENT

Vol. 8, No. 1, 2019, E-ISSN: $2226-6348$ @ 2019 HRMARS

\section{Research Questions}

1. To what extent is the provision and utilization of consumable science materials to improve biology instruction in secondary schools in Ikwo L.G.A.?

2. To what extent is the provision and utilization of science equipment to improve biology instruction in secondary schools in Ikwo L.G.A.?

3. To what extent is the provision and utilization of charts and models to improve the insufficient time allocation for practicals during biology instruction in secondary schools in Ikwo L.G.A.?

4. To what extent is the provision and utilization of practical manuals to improve integration of the theory and practicals during biology instruction in secondary schools in Ikwo L.G.A.?

\section{Hypotheses}

1. There is no significant difference between the mean responses of teachers on the provision and utilization of consumable materials and practical manuals in biology instruction in secondary schools in Ikwo L.G.A.

2. The provision and utilization of science equipment does not significantly influence the use of research terminology in biology instruction in secondary schools in Ikwo L.G.A.

\section{Methodology}

A descriptive survey design was adopted in this study to determine the extent of provision and utilization of instructional media for biology instruction in secondary schools in Ikwo L.G.A. of Ebonyi State.

The population of the study consists of all the senior secondary II and III biology teachers in Ikwo L.G.A. of Ebonyi State. They are 127 in number. (Source Ebonyi State School Board 2017).

Purposive random sampling was employed in selecting thirty two (32) biology teachers from the population for the study. The instrument for data collection is instructional media for biology instruction questionnaire (IMBI). This instrument was subjected to face and content validation by experts in science education and measurement and evaluation.

The reliability of the instrument IMBI was determined using Crombach Alpha Model. A reliability coefficient of 0.714 was obtained for IMBI after trial testing. Data was analyzed using mean and standard deviation for the research questions and t-test for testing the null hypotheses.

\section{Discussion}

The major focus of this study is to find out the extent of provision and utilization of instructional media for biology instruction in secondary schools in Ikwo L.G.A. of Ebonyi State. The findings revealed that thereis provision and utilization of consumable science materials to improve biology instruction in secondary schools in Ikwo L.G.A. of Ebonyi State. This is supported by the average mean of 2.90 in table 1.

This agrees with Igwe (2003) when he said that there is need to provide chemicals, cotton wool, and matches in the laboratory for teachers' use during instruction, and it should not be left until WAEC/NECO is on the doorstep of schools. 
INTERNATIONAL JOURNAL OF ACADEMIC RESEARCH IN PROGRESSIVE EDUCATION AND

DEVELOPMENT

Vol. 8, No. 1, 2019, E-ISSN: $2226-6348$ @ 2019 HRMARS

\section{RESULT}

Research Question I: To what extent does the provision and utilization of consumable science materials improve biology instruction in senior secondary schools in Ikwo Local Government Area, Ebonyi State?

Table I:Provision and utilization of consumable to improve science education.

\begin{tabular}{|l|r|r|r|r|r|}
\hline & $\begin{array}{c}\text { The teachers } \\
\text { have } \\
\text { chemicals to } \\
\text { use }\end{array}$ & $\begin{array}{c}\text { The teachers } \\
\text { have cotton } \\
\text { wool to use } \\
\text { during } \\
\text { Biology } \\
\text { instruction }\end{array}$ & $\begin{array}{c}\text { The teachers } \\
\text { have all } \\
\text { kinds of } \\
\text { markers and } \\
\text { chalks to use }\end{array}$ & $\begin{array}{c}\text { The teachers } \\
\text { have litmus } \\
\text { papers to } \\
\text { test } \\
\text { corrosive } \\
\text { solution }\end{array}$ & $\begin{array}{c}\text { The teachers } \\
\text { have distilled } \\
\text { water to use } \\
\text { during } \\
\text { Biology } \\
\text { instruction }\end{array}$ \\
\hline N Valid & 32 & 32 & 32 & 32 & 32 \\
Mean & 0 & 0 & 0 & 0 \\
Std. Deviation & 3.19 & 3.13 & 3.19 & 2.94 & 0 \\
Missing & .931 & .833 & .931 & 1.014 & 3.03 \\
\hline
\end{tabular}

Table I shows an average mean of 2.90 and standard deviation of .931 indicating that consumable science materials are utilized to improve biology instruction in senior secondary schools in Ikwo L.G.A. of Ebonyi State.

Research Question 2: To what extent is the provision and utilization of science equipment to improve biology instruction in senior secondary schools in Ikwo L.G.A.?

Table 2: $\quad$ Provision and utilization of science equipment to improve science instruction.

\begin{tabular}{|c|c|c|c|c|c|c|}
\hline & & $\begin{array}{c}\text { The teachers } \\
\text { have } \\
\text { weighing } \\
\text { balance in } \\
\text { the } \\
\text { laboratories } \\
\text { to use }\end{array}$ & $\begin{array}{l}\text { The teachers } \\
\text { have beakers } \\
\text { conical flasks } \\
\text { phmeters } \\
\text { bunsen } \\
\text { binners } \\
\text { fridge to use } \\
\text { during } \\
\text { Biology } \\
\text { instructions }\end{array}$ & $\begin{array}{c}\text { The teachers } \\
\text { have } \\
\text { thermomete } \\
r \text { and stop } \\
\text { watches to } \\
\text { we during } \\
\text { biology } \\
\text { instruction }\end{array}$ & $\begin{array}{c}\text { The teacher } \\
\text { have } \\
\text { potometer } \\
\text { use during } \\
\text { biology } \\
\text { instructions }\end{array}$ & $\begin{array}{l}\text { The teachers } \\
\text { have } \\
\text { microscopies } \\
\text { hand lens to } \\
\text { use learning } \\
\text { biology } \\
\text { instruction }\end{array}$ \\
\hline \multirow[t]{2}{*}{$\mathbf{N}$} & Valid & 32 & 32 & 32 & 32 & 32 \\
\hline & Missing & 0 & 0 & 0 & 0 & 0 \\
\hline & & 3.09 & 2.94 & 2.94 & 2.91 & 2.69 \\
\hline \multicolumn{2}{|c|}{ Std. Deviation } & .928 & 1.134 & 1.014 & 1.088 & 1.061 \\
\hline
\end{tabular}

Table 2 shows that science equipment is utilized to improve biology instruction in Ikwo L.G.A. The result shows a grand mean of 3.11 and standard deviation of 0.93 . 
INTERNATIONAL JOURNAL OF ACADEMIC RESEARCH IN PROGRESSIVE EDUCATION AND

DEVELOPMENT

Vol. 8, No. 1, 2019, E-ISSN: $2226-6348 @ 2019$ HRMARS

Research Question 3: To what extent is the provision and utilization of charts and diagrams improve the insufficient time allocation for practicals?

Table 3: $\quad$ Provision and utilization of charts and diagrams to improve time allocation for practicals during biology instruction.

\begin{tabular}{|l|c|c|r|r|r|}
\hline & $\begin{array}{c}\text { The teachers } \\
\text { have } \\
\text { commercial } \\
\text { charts to use } \\
\text { during } \\
\text { biology } \\
\text { instruction }\end{array}$ & $\begin{array}{c}\text { The teachers } \\
\text { have enough } \\
\text { improvised } \\
\text { charts to use } \\
\text { during } \\
\text { biology } \\
\text { instruction }\end{array}$ & $\begin{array}{c}\text { The teachers } \\
\text { have models } \\
\text { to use during } \\
\text { biology } \\
\text { instruction }\end{array}$ & $\begin{array}{c}\text { The teachers } \\
\text { have pictures } \\
\text { of animals } \\
\text { and plantsto } \\
\text { use during } \\
\text { instruction }\end{array}$ & $\begin{array}{c}\text { use during } \\
\text { instruction } \\
\text { the teachers } \\
\text { have ancient } \\
\text { intifacts to }\end{array}$ \\
\hline N Valid & 32 & 32 & 32 & 32 & 32 \\
Mean & 0 & 0 & 0 & 0 & 0 \\
Std. Deviation & 3.19 & 3.13 & 2.72 & 2.94 & 3.09 \\
.931 & .833 & .991 & 1.134 & .928 \\
\hline
\end{tabular}

Table 3 shows that teachers use charts and diagrams to improve the insufficient time allocation for practicals during biology instruction because it has a ground mean of 3.01 and standard deviation .992.

Research Question 4: To what extent does use of practical manual improve integration of the theory and practical during biology instruction?

Table 4A: Provision and utilization of theory and practicals during biology instruction.

\begin{tabular}{|l|r|r|r|r|r|}
\hline & $\begin{array}{c}\text { The teachers } \\
\text { manually use } \\
\text { manual } \\
\text { material in } \\
\text { their leasons }\end{array}$ & $\begin{array}{c}\text { The teachers } \\
\text { The teachers } \\
\text { often use } \\
\text { manuals in } \\
\text { their lessons }\end{array}$ & $\begin{array}{c}\text { money to } \\
\text { provide } \\
\text { manuals for } \\
\text { the students }\end{array}$ & $\begin{array}{c}\text { The teachers } \\
\text { do not use } \\
\text { manuals at } \\
\text { all in their } \\
\text { lessons }\end{array}$ & $\begin{array}{c}\text { The students } \\
\text { cannot } \\
\text { afford a } \\
\text { manual }\end{array}$ \\
\hline N Valid & 32 & 32 & 32 & 32 & 32 \\
Mean & 0 & 0 & 0 & 0 \\
Std. Deviation & 3.19 & 2.94 & 3.03 & 1.91 & 3.13 \\
\end{tabular}


INTERNATIONAL JOURNAL OF ACADEMIC RESEARCH IN PROGRESSIVE EDUCATION AND

DEVELOPMENT

Vol. 8, No. 1, 2019, E-ISSN: $2226-6348$ @ 2019 HRMARS

Table 4B: Total mean and standard deviation

Mean Samples Statistics

\begin{tabular}{|l|l|r|r|}
\hline & Mean & N & $\begin{array}{c}\text { Std. } \\
\text { Deviation }\end{array}$ \\
\hline consumables & 3.0937 & 32 & .46277 \\
manual & 2.8375 & 32 & .37481 \\
Science & 2.9125 & 32 & .54934 \\
Research & 3.0125 & 32 & .37653 \\
\hline
\end{tabular}

Table 4 show the extent of utilization of practical manual to improve instruction. It has an average mean of 2.64 and standard deviation of .895 showing that biology teachers in Ikwo L.G.A. utilize manuals to improve integration of practical and theory during biology instruction.

\section{Discussions}

The result obtained from the study investigating the extent of provision and utilization of instructional media for biology instruction in secondary schools in Ikwo Local Government Area of Ebonyi State revealed that there is provision and utilization of consumable science materials to improve biology instruction in the schools. This is in line with Igwe (2003) who pointed out that there is need to provide chemicals, cotton wool and matches in the laboratories for the teachers' use during instructions and it should not be left until WASSCE/NECOSSCE is on the doorsteps of schools.

The findings also indicated that there is provision and use of science equipment to improve biology instruction in Ikwo L.G.A., Ebonyi State, Nigeria. This agrees with Ezeliora (2001) who noted that without enough instructional materials, it is difficult to realize educational objective. She is of the opinion that instructional materials should be manually provided to the teachers.

The result from table 3 also revealed that teachers utilize to a great extent charts and diagrams to make up for the insufficient time allocation to practicals during biology instruction in senior secondary schools in Ikwo L.G.A., Ebonyi State. This is in line with Igwe (2006) who noted that teachers should be resourceful and always improvise charts and diagrams to improve instructions.

There is also provision and utilization of practical manuals to improve integration of theory and practicals in biology instruction in the schools. This agrees with Nkama (2006) who said that there is need to provide affordable practical biology manuals for students. He asserted that for effective integration of theory and practicals, there must be a provision of manuals for the teachers.

\section{Conclusion}

Biology is an activity-based subject and needs active participation of the students while teachers facilitate learning. Ikwo being a rural area needs the attention of government and effective supervision of the secondary schools for effective teaching and learning especially science subjects of which biology is inclusive. It is therefore the belief of the researchers that the biology 
INTERNATIONAL JOURNAL OF ACADEMIC RESEARCH IN PROGRESSIVE EDUCATION AND

DEVELOPMENT

Vol. 8 , No. 1, 2019, E-ISSN: $2226-6348$ @ 2019 HRMARS

students' performance will improve in view of the provision and utilization of instructional materials for biology instruction in senior secondary schools of Ikwo L.G.A., Ebonyi State, Nigeria.

\section{Recommendations}

To ensure maximum provision and utilization of instructional materials in schools:

- Science teachers should be given hazard/science allowance as incentive for hardwork.

- The schools and ministry of education should carry out effective and regular supervision of schools to ensure that the money for consumables in science instruction is not diverted to private pockets.

- There should be periodic workshops and seminars for biology teachers to upgrade their knowledge and integrate ICT also in their science instructions.

\section{References}

Abdullahi, A. (2006). Laboratory Instruction in Science Teaching, Journal of Science Teachers' Association of Nigeria, 17 (3).

Abimbade, A (2011). Principle and Practice of Educational Technology. Ibadan: International Publishers Limited.

Bello, R. A. (2006). Biotechnology. An Alternative Goldmine. The Vanguard Newspaper. May $18,2006$.

Chidume, E. I. (2009). An Investigation into the Problems Involved in Various Methods of Teaching Biology in the Secondary Schools in Njikoka L.G.A. Unpublished Degree Thesis, U.N.N.

Elliot, A. M. (2007). Laboratory Guide for Biology. New York: Appleton Century - Crofts.

Eya, P. E. (2011). Classification of Instructional Media: The basics of Educational Technology. Enugu. J. T. C. Publishers.

Ezeliora, B. (2001). Laboratory Management and Safety Precautions. Enugu: Divine Love Publication.

Fafunwa, A. B. (2010). New Perspective in Nigerian Education. Lagos: Macmillan Federal Republic of Nigeria (2013). National Policy on Education. $4^{\text {th }}$ Edition. Lagos: NERDC Press.

Igwe I. O. (2006). Principles of Science and Science Teaching in Nigeria (An Introduction). Enugu: Jones Communication Publishers.

Ike, G. A. (2013). Categories of Instructional Media, Non-Projected Instructional Media in F. A. Okwo and G. A. Ike, (Eds). Educational Technology: basic concept and issues. Nsukka: University Trust Publishers.

Maduabum M. A. (2008), Laboratory Manangement in Teaching Biology Effectively. Jos: University Press.

Mbajiorgu, M. N. (2003). Sciences: The teachers perspective. An introduction to Science Education. Institute for Development Studies, University of Nigeria, Enugu, Nigeria.

Njoku, I. (2013). Elements of Educational Planning. Asaba: Satellite Books.

Nkama G. N. (2006). Problems Militating against Biology Practical in Secondary Schools in Afikpo L.G.A. of Ebonyi State. Project seminar presented to the Department of Science Education, Abakaliki, Ebonyi State University.

Ude, V. C. (2011). Relationship between Academic Self-Concept, Worldview and 
INTERNATIONAL JOURNAL OF ACADEMIC RESEARCH IN PROGRESSIVE EDUCATION AND

DEVELOPMENT

Vol. 8, No. 1, 2019, E-ISSN: 2226-6348 @ 2019 HRMARS

Misconceptions in Photosynthesis and Senior Secondary Students' Achievement in Biology in Enugu Urban. Unpublished Ph.D Thesis.

Ude, V. C. \& Onah, E. N. (2017). Influence of ICT as instructional tool in teaching and learning secondary school biology in Enugu South L.G.A., Enugu State. International Journal of Education. 2(1), 198-206. 